УДК 65.012.7

JEL Classification: M41

В. П. ПАНТЕЛЕСВ

доктор економічних наук, професор, професор кафедри бухгалтерського обліку,

декан економіко-статистичного факультету,

Національна академія статистики, обліку і аудиту

\title{
Засади організації внутрішнього контролю підприємств
}

На основі синтезу тематики внутріинього контролю у провідному наукововиробничому виданні Украйни, журналі "Бухгалтерський облікі аудит", та врахування вимог актуальних нормативно-правових актів ијодо основ внутріинього контролю запропоновано перелік фундаментальних засад організацій внутріинього контролю, здійснено ӥх класифікацію за інтегрованою концепиією внутрішнього контролю (моделлю COSO).

Ключові слова організсиія внутріинього контролю, засади організацій внутріинього контролю, бібліометричний метод, семантика, термінологія, модель COSO.

Постановка проблеми та її зв'язок з важливими науковими та практичними завданнями. Аналіз питань, пов'язаних із впровадженням відомих фундаментальних положень управління та використанням передового досвіду внутрішнього контролю в умовах ринку є важливою складовою наукового дослідження інституту внутрішнього контролю підприємств. Прагматична сторона впровадження внутрішнього контролю передбачає встановлення засад організації внутрішнього контролю та підрозділу з проведення такого контролю на підприємстві. Постає питання щодо необхідності надання переконливої оцінки правилам організації внутрішнього контролю та викладення їх у формі засад його організаціі. Оскільки остаточні рішення у вигляді вичерпного та універсального переліку засад внутрішнього контролю відсутнє, триває їх науковий пошук. Це обумовлює важливість критичного аналізу основних положень внутрішнього контролю, що містяться у наукових публікаціях та нормативно-правових актах з провадження внутрішнього контролю.

Огляд попередніх праць та публікацій. У попередніх працях розроблено методологію та організацію внутрішньогосподарського контролю [1], систематизовано елементи організації контролю [1;2], запропоновано принципи ефективності внутрішнього контролю [3], принципи функціонування підсистеми бухгалтерського контролю [4], розглянуто конщептуальні основи внутрішнього контролю [5], розроблено рейтинг основних засад організації підрозділу внутрішнього контролю [5, с. 94-95], запропоновано компоненти системи внутрішнього контролю та параметри їх оцінки [5, с. 45-46], розглянуто компоненти внутрішнього контролю [6], показано, що система внутрішнього контролю входить до суттєвих об $є$ єктів, які розглядає зовнішній аудитор при аудиті фінансової звітності [7]. Понятійний апарат внутрішнього контролю обгрунтовано в $[1 ; 8]$. Утім актуальним питанням залишається формування системи засад організації внутрішнього контролю.

Мета статті - дослідити логіку організації внутрішнього контролю підприємств 3 урахуванням вимог міжнародної практики контролю та запропонувати засади внутрішнњого контролю.

Виклад основних результатів ті їх обрунтування. Специфікою внутрішнього контролю, яка складається із 3 важливих частин: "суб' єкт контролю - контрольні дії - об'єкт контролю", є функціонування суб'єкта контролю та об'єкта контролю на одному рівні управління підприємством. Це потребує більш уважного врахування рис, властивих внутрішньому контролю. Система внутрішнього контролю входить до суттєвих об'єктів, які розглядає зовнішній аудитор при аудиті фінансової звітності. Для обгрунтування засад внутрішнього контролю проведено семантичний синтез тематики внутрішнього контролю у провідному науково-виробничому виданні України, журналі "Бухгалтерський облік і аудит", огляд вимог актуальних нормативно-правових актів

(C) В. П. Пантелеєв, 2017 
щодо засад внутрішнього контролю, а також виконано аналіз результатів анкетування респондентів.

Синтез тематики засад внутріинього контролю у провідноу наукововиробничому виданні Украйни. Забезпечення впевненості власника у тому, що бізнеспроцеси на його підприємстві здійснюються за визначеним ним сценарієм, досягається, крім іншого, ефективними заходами контролю, аудиту, інвентаризації тощо. Тому предметом досліджень науковців стає вирішення проблем аудиту, контролю, відповідальності контролера. Для розкриття перспектив розвитку внутрішнњого контролю та обгрунтування його засад використано бібліометричний метод. За його допомогою проаналізовано зміст тематики і застосування доречної термінології у наукових статтях авторів фахового науково-виробничого журналу України “Бухгалтерський облік i аудит" за роки його видання (1994-2015). Журнал є лідером вітчизнялного інформаційного простору щодо обговорення актуальних наукових та практичних проблем бухгалтерського (галузевого, фінансового, управлінського, податкового тощо) обліку, аналізу, контролю та аудиту (як зовнішнього, так і внутрішнього).

Формування та становлення наукового науково-практичного журналу “Бухгалтерський облік і аудит" відбувалося у тісному зв'язку із фундаментальним переглядом та реформуванням системи управління економікою України, систем бухгалтерського обліку, державної статистики, оподаткування, аналізу, контролю та аудиту, а також знаковими подіями національного і світового рівня: прийняття Закону України "Про аудиторську діяльність" (1993р.), “азіатська" фінансова криза 1997-1998 років, прийняття Закону України "Про бухгалтерський облік та фінансову звітність в Україні" (1999 р.), розроблення національних нормативів аудиту в кінці ХХ ст., потім відмова від них та використання міжнародних стандартів аудиту (МСА) як національних (2004 p.), вступ України до СОТ (травень 2008 р.), світова фінансова криза початку XXI ст. (почалася у вересні 2008 р. і триває досі), набуття чинності Податковим кодексом України (2011р.), підписання Угоди про асоціацію між Україною, з однієї сторони, та Європейським Союзом, Свропейським співтовариством з атомної енергії і їхніми державами-членами, з іншої сторони (2014р.) [10], запровадження підприємствами та установами України МСБО та МСФЗ тощо.

У роботах авторів науково-практичного журналу загалом висвітлюється наукове життя бухгалтерів - викладачів, науковців, організаторів науки; прирощення фахових знань, насамперед 3 проблем функціонування підприємств, професійного контролю, зміцнення громадянського суспільства та ін. Крім того, журнал публікує актуальні матеріали з відгуками на глобальні тенденції у бізнесі, контролі та аудиті на початку XXI ст. Вони пов'язані із навмисним викривленням менеджментом відомих світових публічних (акціонерних) компаній фінансової звітності, про які стало відомо лише у перші роки нового сторіччя: справа Enron у 2001 р. та WorldCom у 2002 р. за участі аудиторської організаціï Arthur Andersen у США, Parmalat у 2004 p. у Iталіï, Ahold у Нідерландах у 2003 р., HIH у 2001 р. в Австралії та ін. Такі дії підірвали довіру інвесторів до світових ринків цінних паперів та підтверджену зовнішніми аудиторами достовірність інформації фінансових звітів компаній (яка значною мірою грунтувалася на "дієвому" внутрішньому контролі), акції яких котуються на біржах.

Слід зазначити, шо протягом 1994-2015 рр. контроль був другою за значимістю тематикою в журналі (до 10\% від загальної статей), а перше місце у належить тематиці з обліку [9].

Цільове вивчення змісту публікацій журналу “Бухгалтерський облік і аудит" за допомогою семантики (розділу лінгвістики, що вивчає смислове значення одиниць мови) дозволило провести класифікацію використовуваних термінів, пов'язаних 3 контролем (табл. 1).

Класифікацію термінів із внутрішнього контролю проведено у табл. 1 за кожні 5 років протягом періоду 1994-2015 pр. за логічним порядком: від загальних положень до прикладних питань 3 контролю. Терміни з контролю, використовувані авторами журналу, систематизовано у хронологічному порядку, тобто спочатку наведено слова і словосполучення, які вперше зустрілись у публікаціях авторів журналу ще в кінщі XX ст., потім, не повторюючи інформацію попередніх років, - лише нові оригінальні терміни. 
Групування основних термінів із внутрішнього контролю у публікаціях журналу “Бухгалтерський облік і аудит” за 1994-2015 роки

\begin{tabular}{|c|l|}
\hline Роки & \multicolumn{1}{|c|}{ Базові терміни з внутрішнього контролю } \\
\hline $1994-1995$ & $\begin{array}{l}\text { контрольні дії, контрольний продукт, контрольні точки, самоконтроль, } \\
\text { система внутрішнього контролю, внутрішній контроль }\end{array}$ \\
\hline $1996-2000$ & $\begin{array}{l}\text { оперативний контроль, фінансовий контроль, жорсткий контроль, вітчиз- } \\
\text { няна ревізійна школа }\end{array}$ \\
\hline $2001-2005$ & $\begin{array}{l}\text { механізм контролю, типологія помилок, альтернативні процедури контр- } \\
\text { олю, система контролю, контрольні рахунки, внутрішній бухгалтерський } \\
\text { контроль, внутрішній фінансовий контроль, контрольний процес, поси- } \\
\text { лення контролю, зміни контрольного середовища, належний контроль, } \\
\text { контроль, моніторинг, якість контролю }\end{array}$ \\
\hline $2006-2010$ & $\begin{array}{l}\text { концептуальна основа контролю, контрольні функції, контроль якості, } \\
\text { Базель II, КICO (контрольно-інформаційна система обліку), суспільний } \\
\text { нагляд, моніторинг, INTOSAI }\end{array}$ \\
\hline $2011-2015$ & $\begin{array}{l}\text { ідеологія контролю, контрольна інформація, шахрайство, трикутник } \\
\text { шахрайства, картка ризиків, податковий контроль, ефективність контр- } \\
\text { олю, СОSO, ASSAI, надання впевненості, завдання з надання впевненості }\end{array}$ \\
\hline
\end{tabular}

Джерело: складено автором

Як свідчать дані табл. 1, із самих перших випусків на сторінках журналу з'явилися актуальні терміни: система внутрішнього контролю, самоконтроль, модель стандарту контролю. Значно розширилося поле використання контролю, ефективність контролю, ідеологія контролю та ін

Семантичний синтез термінології з контролю дозволяє стверджувати, що статті в журналі з питань застосування сучасних прийомів внутрішнього контролю актуальні для свого часу. Здійснений огляд термінів в порядку хронології застосування в публікаціях авторів-науковців за історичний відрізок часу у 22 роки свідчить, шо в міру розвитку бізнесу, управління, контролю та відповідної термінології, вона (термінологія) доречно та за призначенням застосовується у статтях журналу. Але незважаючи на висвітлення у статтях журналу положень, принципів, вимог, правил, сучасних прийомів та ін. щодо внутрішнього контролю, автори так і не спромоглися дати вичерпну і обгрунтовану відповідь стосовно термінології, організації та класифікації внутрішнього контролю.

Вимоги актуальних нормативно-правових актів щңодо засад внутрімнього контролю. Угодою про асоціацію між Україною та ЄС [10] щодо економічного та галузевого співробітництва регламентовано норми законодавства про заснування та діяльність компаній, корпоративне управління, бухгалтерський облік та аудит. Для забезпечення довіри інвесторів до загальнонаціональних економічних показників слід дотримуватися принципів корпоративного управління Організації економічного співробітництва та розвитку (OECP), що містяться у Додатку XXXIV до угоди про заснування цієі організаціі. Хоча на процес управління та ухвалення рішень впливають багато чинників, які мають велике значення для досягнення успіху в довгостроковій перспективі, ці принципи стосуються проблем управління, які виникають внаслідок розмежування власності та контролю. Так, рада корпорації повинна виконувати певні ключові функції, у тому числі переглядати корпоративну стратегію, основні плани дій, політику управління ризиками, річні бюджети та бізнес-плани, окреслювати орієнтири ефективності, здійснювати нагляд за виконанням бізнеспланів, контролювати основні витрати тощо. Незалежні члени ради можуть зробити вагомий внесок у процес прийняття рішень і привнести елемент об' єктивності в оцінку діяльності ради та правління, наприклад, у питаннях оплати праці членів правління, планування наступництва посад, змін у системі корпоративного контролю, вжиття заходів щодо захисту товариства від поглинання, укладання важливих угод і проведення аудиту [11]. 
Згідно з міжнародними та національними стандартами корпоративного управління (збірник кодексів та принципів), механізми внутрішнього контролю повинні забезпечувати повноту корпоративних даних. Належна перевірка та сертифікація наявності ефективних механізмів контролю та надійності даних (особливо стосовно інформації, що розкривається і оприлюднюється) повинна проводитися у повному обсязі. Крім того, рада повинна регулярно переглядати процедури з метою гарантування ефективності внутрішньої системи контролю, що допоможе постійно підтримувати на високому рівні її здатність приймати рішення та точність звітності шодо результатів фінансової діяльності [12].

Зазначені вище положення нормативно-правових актів мають універсальний характер щодо внутрішнього контролю; реальні аспекти такого контролю будуть унікальними для кожного підприємства.

Класифікація засад внутріинього контролю за правилами COSO. 3 кінця XX ст. у світі набуває поширення інтегрована конщепція внутрішнього контролю, яка отримала назву COSO на честь Комітету організацій-спонсорів Комісії Тредвея (англ. The Committee of Sponsoring Organizations of the Treadway Commission) $[1 ; 2 ; 5 ; 6 ; 7]$.

За вимогами COSO контроль на суб' єктах господарювання передбачає відображення його у вигляді системи внутрішнього контролю, яка складається з 5 складових: nо-перше, це середовище контролю, тобто “атмосфера" на підприємстві, яка впливає на свідомість персоналу всіх рівнів, забезпечуючи виробничу дисципліну, відповідальний стиль роботи і ставлення персоналу до внутрішнього контролю; no-друге, це процес оцінювання ризиків суб' єктів господарювання - ідентифікація ділових ризиків стосовно цілей фінансової звітності, прийняття рішень щодо дій у відповідь на ці ризики і аналіз результатів цих дій; nо-третє, це заходи контролю (дії), тобто низка регламентів та процедур (дозволи, розподіл обов'язків, перевірки, звіряння, звіти про діяльність та контроль, безпеку активів тощо) для унеможливлення або виявлення некоректних змін у комп'ютерних програмах, доступ до яких можна обмежити, створення окремих довідників, бібліотек, здійснення контролю та документування записів; по-четверте, це інформаційні системи та комунікації для формування фінансової та нефінансової інформації про діяльність самого підприємства та про дотримання ним процедур законодавства та забезпечення зв' язків із зовнішнім середовищем; інформаційні системи передбачають, що фінансова звітність, процедури та бухгалтерські записи призначені для ініціювання, обліку, оброблення та відображення у звітності операцій підприємства, процедур ведення обліку, відповідності активів, зобов'язань та капіталу; no-n 'яте, це моніторинг ефективності роботи внутрішнього контролю, який включає своєчасне оцінювання заходів контролю, виконання необхідних коригуючих дій у відповідь на зміни в умовах діяльності; моніторинг передбачає, що недоліки внутрішнього контролю, виявлені у ході таких контрольних заходів, слід доводити до відома керівнищтва та усувати для забезпечення безперервного вдосконалення системи внутрішнього контролю.

Модель COSO має і певні обмеження. Внутрішній контроль $є$ видом діяльності людини, яка не може уникнути помилок у судженнях або висновках. Внутрішній контроль може бути змінений у результаті змови між співробітниками або в результаті тиску з боку вищого керівництва. Практика свідчить, що при застосуванні комплексної моделі, яка запропонована COSO, потрібно враховувати обмеження певних складових цієі моделі та дотримуватися всіх її вимог, що може призвести до значної кількості перевірок, не завжди результативних і виправданих. Варіантами рішення $є$ вибір та дотримання пріоритетних, другорядних або незначних засад організації контролю або утворення на підприємствах власних моделей сполучення “ризик - контроль" на основі моделі COSO, концентруючи увагу на тих складових контролю, які $є$ головними (нагадуємо, що їх п’ять).

Правильна організація внутрішнього контролю дозволяє ефективно використовувати обмежені ресурси підприємства, досягати значного ефекту. На основі систематизації основних засад внутрішнього контролю, які містяться у нормативних документах та рекомендаціях з урахуванням досвіду ринкової економіки, запропоновано перелік основних засад організації внутрішнього контролю (табл. 2). 
Основні засади організапії

внутрішнього контролю підприємства

\begin{tabular}{|c|c|}
\hline № 3ไII & Перелік засад \\
\hline 1 & Наявність та дотримання етичних цінностей працівниками підприсмства \\
\hline 2 & Компетентність співробітників підприємства \\
\hline 3 & $\begin{array}{l}\text { Зацікавленість керівництва у функціонуванні внутрішнього контролю підпри- } \\
\text { ємства }\end{array}$ \\
\hline 4 & Стиль управління та політика керівництва підприємства \\
\hline 5 & Правила розподілу керівництвом підприємства відповідальності і повноважень \\
\hline 6 & $\begin{array}{l}\text { Персональна відповідальність суб’єктів внутрішнього контролю підприємства } \\
\text { (підрозділів та служб́ підприємства) }\end{array}$ \\
\hline 7 & Ідентифікація та оцінювання ризиків \\
\hline 8 & Аналіз ризиків та управління ризиками \\
\hline 9 & $\begin{array}{l}\text { Адекватне реагування на зміни у зовнішньому та внутрішньому середовищі } \\
\text { підприємства }\end{array}$ \\
\hline 10 & Контроль поточної діяльності підприємства та проведення перевірок \\
\hline 11 & Видача дозволів на здійснення операцій, наявність санкцій та підтверджень \\
\hline 12 & Належна регламентація внутрішнього контролю \\
\hline 13 & Своєчасне реагування на інформацію отриману зі звітів \\
\hline 14 & Гарантія безпеки активів та файлів \\
\hline 15 & $\begin{array}{l}\text { Формування системи планів, норм, правил та звітів про діяльність персоналу } \\
\text { та підрозділів підприємства }\end{array}$ \\
\hline 16 & Виконання встановлених норм, правил, планів \\
\hline 17 & Ефективний обмін (циркуляція) інформації про діяльність підприємства \\
\hline 18 & Ідентифікація та реєстрація всіх правомірних операцій підприємства \\
\hline 19 & Суцільна реєстрація всіх фактів господарського життя підприємства \\
\hline 20 & Функціонування прикладних інформаційних систем \\
\hline 21 & $\begin{array}{l}\text { Управління та нагляд керівництва підприємства за дотриманням своєчасності } \\
\text { та повноти контрольних заходів }\end{array}$ \\
\hline 22 & $\begin{array}{l}\text { Здійснення відповідних коригуючих заходів через зміни умов діяльності } \\
\text { підприємства }\end{array}$ \\
\hline 23 & Підтвердження результатів внутрішнього контролю \\
\hline 24 & Стан документування внутрішнього контролю \\
\hline 25 & Потенційне заміщення суб'єктів внутрішнього контролю підприємства \\
\hline
\end{tabular}

Джерело: складено автором

Перелік засад організації внутрішнього контролю складено у формі роз'яснень, зрозумілих фахівцям-економістам, зміст засад передбачає однозначне тлумачення, їх кількість незначна та кратна кількості складових системи внутрішнього контролю.

Результати анкетування слухачів. Автором вивчено думки стосовно засад внутрішнього контролю. Біло опитано слухачів груп із підвищення кваліфікації за направленням служби зайнятості в Київському університеті ринкових відносин у 2016 p. Виконавцями завдання були слухачі трьох груп, які є економістами за професією (менеджери, бухгалтери, внутрішні аудитори, спеціалісти з управління). Слухачам пропонувалося скласти рейтинг основних вимог до підрозділу внутрішнього контролю на підприємств, бажано 3 використанням власного досвіду практичної роботи, а також провести ранжування вимог до організації внутрішнього контролю на пріоритетні, другорядні або незначні [5]. Аналіз результатів анкетування не дозволив отримати переконливі аргументи щодо проведення класифікації та встановлення відповідних 
засад організації внутрішнього контролю, що зумовлює продовження пошуку вирішення проблеми білыш ефективними засобами.

Напрями подалыших досліджень. Внутрішній контроль у системі обліковоаналітичного забезпечення підприємства $\epsilon$ специфічною підсистемою управління ним, яка має три головні результати: по-перше, використовуючи інформацію бухгалтерського, внутрішньогосподарського (управлінського) обліку, формуючи власну інформаційну базу, проводячи аналіз діяльності, застосовуючи контрольні заходи, служба внутрішнього контролю встановлює та оцінює відхилення від завдань, формує докази істини; по-друге, засобами контролю знаходяться відхилення і порушення у діяльності, які повинні бути виправлені, у чому зацікавлені власники, менеджери та персонал, по-третє, аудитор, покладаючись на дієву систему внутрішнього контролю, висловлює свою обгрунтовану думку про достовірність бухгалтерського обліку та фінансової звітності, підтверджує (чи не підтверджує) стан обліку та звітності і створює позитивний імідж підприємства на ринку

Попри певні обмеження методики опитування і оброблення отриманих від респондентів результатів, вона залишається дієвим науковим інструментом. Потрібно вдосконалювати опитувальники, включаючи до них запитання про складові системи внутрішнього контролю за правилами COSO, соціальну відповідальність, забезпечення безпеки підприємства, чинники успішної діяльності в умовах кризи та ін. Складання анкет, їх оброблення та інтерпретація збагачують інструментарій дослідження внутрішнього контролю. Також доречно поліпшувати методичні прийоми оброблення отриманих даних.

Зараз спостерігається певне “відродження" проблематики внутрішнього контролю, особливо на тлі низької його результативності у період останніх світових фінансових криз. Згідно зі ст. 101 Угоди [10] "Постачальники договірних послуг” кожна сторона дозволяє надання послуг на своїй території постачальниками договірних послуг іншої сторони а саме: бухгалтерський облік та бухгалтерські послуги, консультаційні послуги щодо оподаткування, послуги з управлінського консультування та послуги, пов 'язані 3 управлінським консультуванням, тощо. Вищевказане вносить коригування у зміст

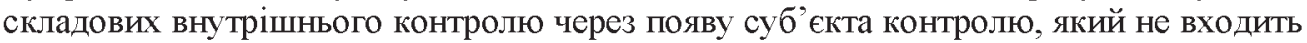
до складу підприємства, і сприяє як появі на ринку України якісних та ефективних послуг з організації внутрішнього аудиту з боку іноземних партнерів, так і наданню аналогічних конкурентоспроможних послуг з боку бізнесу України на території країн $€ С$. Нині широкого розвитку набуває внутрішній аудит, комплаєнс-контроль, форензік та інші напрями контролю.

Висновки. 3 урахуванням сучасних поглядів на зміст внутрішнього контролю, вимог міжнародної практики контролю запропоновано перелік з 25 основних засад організації внутрішнього контролю підприємства, які охоплюють основні аспекти організації внутрішнього контролю підприємств. При формуванні цього переліку знайшли належне відображення два різні підходи до проведення контролю: контроль, що грунтується на встановленні відхилень від норм, правил (традиційний підхід), та контроль ключових об'єктів, точок контролю (цільовий підхід). Для усунення несумісності традиційних підходів до організації контролю та COSO потрібно впроваджувати сучасні елементи організації внутрішнього контролю у практику контролю та навчальний процес, розширювати перелік компонентів внутрішнього контролю. При впровадженні засад внутрішнього контролю слід враховувати фундаментальні положення внутрішнього контролю: прийнятність методології контролю, пріоритетність вагомих областей контролю, суцільність внутрішній контроль, системність і ефективність внутрішнього контролю тощо.

\section{Список використаних джерел}

1. Пантелєєв В. П. Внутрішньогосподарсыкий контроль: методологія та організація: моногр. К: ДП "Інформ.-аналіт. агентство", 2008. 49 с.

2. Пантелеєв В. П. Аудит: навч. посіб. К.: "ВД "Професіонал", 2008. 400 с.

3. Бурцев В. В. Организация системы внутреннего контроля коммерческой организации. М.: Экзамен, 2000. 320 с. 
4. Садекова А. М. Аудиторська оцінка ефективності бухгалтерського контролю (на матеріалах підприємств 3 виробництва машин та устаткування Донецького регіону): автореф. дис. ... канд. екон. наук: 08.00.09. Одеса: Б. в., 2007. 16 с.

5. Резниченко С. М. и др. Современные системы внутреннего контроля: учебное пособие. Ростов-н/д: Феникс, 2016. 510 с.

6. Каменська Т. О., Редько О. Ю. Внутрішній контроль і аудит в управлінні: практ. посіб. К.: ДП “Інформ.-аналіт. агентство", 2015. 375 с.

7. Міжнародні стандарти аудиту, надання впевненості та етики / Пер. з англ. О. В. Селезньова та ін. К.: ТОВ ІАМЦ АУ “СТАТУС", 2012. 1028 с.

8. Мельник Л. Г. Экономика и информация: экономика информации и информация в экономике: Энциклопедический словарь. Сумы: ИТД “У ниверситетская книга", $2005.384 \mathrm{c}$.

9. Пантелеєв В. П. Простір науково-практичного журналу “Бухгалтерський облік і аудит" як форум висловлення думок щодо актуальних питань обліку, аналізу, аудиту, оподаткування в Україні // Бухгалтерський облік і аудит. 2016. № 3. С. 35-46.

10. Угода про асоціацію між Україною, з однієї сторони, та Європейським Союзом, Європейським співтовариством 3 атомної енергії і їхніми державами-членами, 3 іншої сторони. URL: http://zakon3.rada.gov.ua/laws/show/984 011

11. Принципи OECP щодо корпоративного управління. URL: bank.gov.ua/doccatalog/document.jsessionid...?id=36989

12. Міжнародні та національні стандарти корпоративного управління (збірник кодексів та принципів). URL:

pmguinfo.dp.ua/images/documents/korp_otnosheniya/stand_korp_upravlenija.pdf

В. П. ПАНТЕЛЕЕВ,

доктор экономических наук, профессор, профессор кафедры бухгалтерского учета, декан экономико-статистичного факультета, Национальная академия статистики, учета и аудита

\section{Основы организации внутреннего контроля предприятий}

На основе синтеза тематики внутреннего контроля в ведущем научнопроизводственном издании Украины, журнале «Бухгалтерский учет и аудит», и учете требований актуальных нормативно-правовых актов относительно основ внутреннего контроля предложен перечень фундаментальных основ организации внутреннего контроля, осуществлена их классификация по интегрированной концепџии внутренного контроля (модели COSO).

Ключевые слова организачия внутреннего контроля, принцииы организации внутреннего контроля, библиометрический метод, семантика, терминология, модель COSO.

V. P. PANTELEIEV,

Dr. Sc. (Economics), Prof.

Dean of the Faculty of Economics and Statistics, Professor of Department of Accounting

National Academy of Statistics, Accounting and Auditing

\section{The Principles of Organization of Internal Control at Company Level}

The question to give a convincing assessment of the Rules of the internal control and present them in form of principles of organization of internal control. Since the final decision in the form of an exhaustive list and universal principles of internal control is no scientific research continues these principles. It is necessary to examine the logic of the main provisions of the organization's internal control due consideration of the requirements of international 
practice controls and propose principles of internal control. For this purpose, a critical review of the main provisions of internal control contained in the publications and in the regulations on internal control proceedings is conducted.

Synthesis of articles from the Ukrainian scientific and practical journal "Accounting and Audit" for the 1994-2015 biennium points out that despite the coverage of provisions, principles, requirements, mules and other modern techniques, the problem of organization and classification of internal control has not been appropriately addressed.

The above basic concepts in publications on the organization of internal control were used in the formation of a set of principles of control.

According to the OECD requirements, internal control includes risk management, cost control, change in control, complete information to guarantee the effectiveness of internal control systems, providing the ability to make decisions and so on. COSO model contains a complete nomenclature of five components.

The results of the trainees' questioning have not given compelling arguments for classifying and establishing relevant principles organization and internal controls.

A nomenclature of the basic principles of organization of internal control is proposed, consisting of 25 elements, which cover key aspects of organization of internal control at company level. Proper organization of internal control can effectively use the limited company resources, to achieve a significant effect.

Keywords: organization of internal control, principles of internal control organization, bibliomethric method, semantics, terminology, COSO model.

Посилання на статтю:

Пантелеєв В. П. Засади організації внутрішнього контролю підприємств // Науковий вісник Національної академії статистики, обліку та аудиту: зб. наук. праць. 2017. № 1-2. С. 15-22. 